\title{
Plany życiowe i marzenia mieszkańców domów pomocy społecznej dla osób z niepełnosprawnością intelektualną
}

\begin{abstract}
Beata Tylewska-Nowak, Plany życiowe i marzenia mieszkańców domów pomocy społecznej dla osób z niepetnosprawnościq intelektualna [The life plans and dreams of residents of social care homes for people with intellectual disabilities]. Interdyscyplinarne Konteksty Pedagogiki Specjalnej, nr 17, Poznań 2017. Pp. 179-31. Adam Mickiewicz University Press. ISSN 2300-391X

Adult residents of residential homes for people with intellectual disabilities are a group of people, who are rarely asked for opinion, even i fit comes to their own case. What are they future plans and wishes, what do they dream about, how often do they do it and what is the characteristic of those thoughts. In this article I present an attempt to annalize those topics using material I colected through narrative and nondirective interviews.
\end{abstract}

KEY WORDS: future plans, dreams, residential homes, adults with intellectual disabilities

\section{Uzasadnienie wyboru tematu}

Podczas przeprowadzanych przeze mnie badań biograficznych dotyczących życia codziennego i dorosłości mieszkańców domów pomocy społecznej dla osób z niepełnosprawnością intelektualną wśród wielu wątków pojawił się także, ujęty w tytule artykułu, te- 
mat dotyczący planów i marzeń. W tym miejscu muszę zaznaczyć, że badania prowadzone były metodą wywiadów narracyjnych i wywiadów swobodnych, w związku z tym brali w nich udział mieszkańcy, którzy byli w stanie takich wywiadów udzielić. Były to osoby ze zdiagnozowaną niepełnosprawnością intelektualną (w stopniu umiarkowanym lub lekkim). Przedstawiony w referacie wąski wycinek badań wchodzi w skład szerszego projektu badawczego dotyczącego dorosłości mieszkańców domów pomocy społecznej dla osób z niepełnosprawnością intelektualną. Wątek dotyczący planów i marzeń pojawiał się bądź spontanicznie w narracjach moich rozmówców (niezwykle rzadko), bądź jako odpowiedź na pytanie skierowane przeze mnie bezpośrednio do badanego. Gdy analizowałam materiał badawczy, nasunęły mi się pewne refleksje, które postaram się omówić w artykule.

Funkcjonowanie człowieka jest z reguły celowe, podporządkowane pewnym planom i marzeniom. Plany stanowią podstawę do podejmowania określonych działań, wyprzedzają je, są podstawą zarówno kontynuacji, jak i zaniechania działań. Niepełnosprawność intelektualna, związane $\mathrm{z}$ nią ograniczenia poznawcze i specyfika życia w instytucji mają wpływ na tworzenie i realizację planów i marzeń. Analiza materiału z wywiadów pozwala w pewnym stopniu opisać, jak mieszkańcy domów pomocy społecznej określają swoje plany życiowe i marzenia.

\section{Kilka refleksji teoretycznych związanych z pojęciami: plan życiowy i marzenia}

Nancy Cantor i John F. Kihlstrom ${ }^{1}$ ujmują plan życiowy jako zadanie życiowe, czyli problem, który został sformułowany i uznany przez jednostkę za własny, przy czym jednostka jest zaangażowana, poświęca swoją energię i czas, zmierzając do rozwiązania tego pro-

${ }^{1}$ N. Cantor, J.F. Kihlstrom, Personality and social intelligence, Englewood Cliffs, New Jersey, Prentice-Hall 1987. 
blemu. Jest więc to codzienne życiowe działanie człowieka, jego codzienna życiowa aktywność. Włodzimierz Szewczuk ${ }^{2}$ mówi o jednym planie życiowym jako o systemie celów, do realizacji których zmierza człowiek, a także wiążących się z nim zasadach realizacji owych celów. Tadeusz Mądrzycki ${ }^{3}$ planem życiowym określa przyjęty przez jednostkę lub stworzony przez nią cel główny i powiązane z nim cele pomocnicze oraz zasady operacjonalizacji tych celów. Jeden plan życiowy zawiera zatem wiele planów - działań, jego realizacja jest rozłożona na dłuższy okres czasu i jest on ważny dla jednostki. Mądrzycki ${ }^{4}$ uważa, że określenie "plan życiowy” może być stosowane zamiennie z terminem "cel życiowy", przy czym wskazuje, że cel określa tylko zamiar, punkt do którego człowiek dąży, zaś plan życiowy zawiera w sobie także sposób działania drogi realizacji. Autor odróżnia także plan życiowy od planów pojedynczych zadań, które są realizowane przez jednostkę zazwyczaj w krótszym czasie (dla przykładu planem życiowym będzie np. samodzielne zamieszkanie we własnym mieszkaniu, a zadaniem pojedynczym uzbieranie pieniędzy na wymarzony dywan). Plany życiowe różnią się:

- zakresem - liczbą planów składowych oraz czasem i trudem potrzebnym do ich realizacji,

- treścią - bogactwem treści i jej różnorodnością,

- różnorodnością - obejmują jedna lub więcej dziedzin życia,

- liczbą - od kilku do kilkunastu u danej osoby,

- stopniem trudności - który odzwierciedla poziom aspiracji,

- stopniem ważności - bardziej znaczące, przynoszą więcej satysfakcji ale wymagają większego trudu i realizowane są przez dłuższy czas,

2 W. Szewczuk, Psychologia. Zarys podręcznikowy, T. 2, Wydawnictwo Naukowe PWN, Warszawa 1966.

3 T. Mądrzycki, Osobowość jako system tworzacy i realizujący plany Nowe podejście, Wydawnictwo Uniwersytetu Gdańskiego, Gdańsk 2002, s. 133.

4 Ibidem.

5 Ibidem, s. 133-138. 
- realnością - która związana jest z oceną realnych warunków zewnętrznych i wewnętrznych realizacji planu,

- szczegółowością - tworzeniem zarysu i szczegółowej „mapy planu", najczęściej plany długofalowe mają bardziej ogólny zarys, a krótkofalowe są szczegółowo przygotowane,

- elastycznością - czyli dostosowaniem planu do działania,

- poziomem integracji,

- hierarchią.

Wszystkie powinny być zgodne z normami moralnymi zarówno z uwagi na przyjęte cele, jak i sposób ich realizacji. Różnorodność planów jest wynikiem tak cech osobowości jednostki tworzącej plany, jak i warunków społecznych, w których żyje.

Słowo „marzenia” utożsamiane jest z określeniami: fantazjowanie, imaginacja, wyobrażenia i zestawiane nie tyle z celami (planami), jak z emocjami. Marzenia wg Tomasza Maruszewskiego ${ }^{6}$ są natomiast jedną z form myślenia twórczego, nieukierunkowanego, autystycznego (czyli myślenia osobistego, idiosynkratycznego, obejmującego fantazje, marzenia, reakcje nieświadome i idee niesprawdzalne za pomocą rzeczywistości zewnętrznej) ${ }^{7}$. Bronisława Dymara marzenia ujmuje jako „aktywność wyobrażeniowo-myślową, której przedmiotem jest zaspokojenie dążeń, zamierzeń dotyczących własnego życia, często ściśle osobistego"8. Marzenia można podzielić na dzienne i senne. W tym opracowaniu skupiam się tylko na marzeniach dziennych, którym towarzyszy świadomość i duża rozpiętość czasowa. Dotyczą zarówno przeszłości, jak i teraźniejszości oraz przyszłości, a ich treść przeważnie związana jest z relacjami społecznymi, sukcesem, bohaterstwem itp. Składają się ze zdarzeń, w którym marzący jest zwykle głównym bohaterem, oraz scenografii, czyli przedmiotów, które są pożądane lub wypierane ${ }^{9}$. Ma-

6 T. Maruszewski, Psychologia poznania, Gdańskie Wydawnictwo Psychologiczne, Gdańsk 2002, s. 342.

7 P. Zimbardo, Psychologia i życie, PWN, Warszawa 1999, s. 413.

${ }^{8}$ Dziecko w świecie marzeń, red. B. Dymara, Oficyna Wydawnicza "Impuls”, Kraków1999, s. 21.

9 T. Maruszewski, op. cit. 
rzenia, w odróżnieniu od planów, nie muszą być realne i wiązać się z konkretnym planem działania. Tadeusz Mądrzycki, zestawiając plany i marzenia, wskazuje na powyższe cechy. O planach mówi, gdy są one związane z wyborem wartościowych celów, które mają realne szanse na realizację i są połączone $\mathrm{z}$ decydowaniem o przyszłych działaniach. Marzenia zaś uważa za podyktowane emocjami, nieodnoszące się do konkretnych postanowień, pozostające w sferze wyobraźni pragnienia, w których nie uwzględnia się warunków ich urzeczywistnienia ${ }^{10}$.

\section{Plany dorosłych mieszkańców domów pomocy społecznej}

W przeprowadzonych przeze mnie wywiadach, jak już wspomniałam we wstępie, wątki dotyczące planów życiowych w spontanicznej wypowiedzi pojawiały się niezwykle rzadko. Najczęściej dotyczyły przyszłości związanej z miejscem zamieszkania lub zakupami. Te dotyczące przyszłości badanych, które pojawiły się w spontanicznej narracji, nazwałabym "planami wytłumaczonymi”, będącymi jednocześnie nie tyle planem, ile być może wytłumaczeniem obecnego stanu rzeczy. Moi rozmówcy wiązali swoje plany przede wszystkim ze swoją teraźniejszością, z tym, co znane, oswojone, dostępne:

To już chyba tu na zawsze zostaniemy. Bo tak rodziny się nie poskłada $i$ tak sie nie posktada. Bo brat ma swoja rodzinę. A ja siedzę tutaj. A bratu nie będe przeszkadzat. Bo on też musi, dzieci iść do szkoty, uszykować $i$ swoje sprawy pozałatwiać.

No tu. Tu. No bo tak się człowiek do wszystkich przyzwyczai, nie? Do koleżanków, do salowej, do opiekunek. Do wszystkich. Tak to by się chciało osobno mieszkać, to by się nawet tęsknito.

Pani, ja to już tu będe, tu żyć nie umierać, bo tak to by trza o wszystko się martwić, a tu jeść co mam, spać gdzie mam i o nic nie muszę się martwić.

${ }^{10}$ T. Mądrzycki, op. cit., s. 130-132. 
Trzecia przytoczona wypowiedź wskazuje wyraźnie na to, jak środowisko zewnętrzne, w tym przypadku dom pomocy społecznej, wpływa na plany życiowe mieszkańców. Instytucja, zapewniając podstawowe potrzeby, jednocześnie zwalnia mieszkańca od obowiązku zatroszczenia się o siebie, co w przypadku osób z niepełnosprawnością intelektualną wydaje się być uzasadnione. Jednocześnie z wypowiedzi badanych można wywnioskować, że zdają sobie oni sprawę z tego, że zdjęto z nich tę odpowiedzialność, przez co ich życie stało się łatwiejsze, ale jednocześnie właśnie brak odpowiedzialności powoduje też zanik konieczności/możliwości planowania. Plany po prostu nie są im potrzebne w codziennym życiu, bo z jednej strony mają poczucie stabilizacji i pewnego bezpieczeństwa, a z drugiej wiedzą, że kontrola ich życia jest na zewnątrz, ktoś - opiekunowie, dyrektor - zaplanuje najbliższe dni, a nawet życie. Wszak codzienność $\mathrm{w}$ instytucjach jest zaplanowana m.in. poprzez rozkład dnia, wyznaczony choćby porą posiłków i zajęć terapeutycznych czy ewentualnych dodatkowych atrakcji. Jednocześnie można przypuszczać, że taki stan (braku konieczności planowania) towarzyszy im od zawsze, wynika z wychowania osób z niepełnosprawnością intelektualną. Co ciekawe, w niektórych wypowiedziach pojawiały się zdania świadczące o tym, że nawet udział $\mathrm{w}$ dodatkowych atrakcjach, takich jak zabawy andrzejkowe, bale karnawałowe, zawody sportowe, nie $\mathrm{w}$ pełni zależy od samych podopiecznych, często personel wyznacza, który z mieszkańców będzie uczestniczył w danej imprezie. Oczywiście mieszkańcy wyrażają chęć lub brak chęci wyjazdu, ale niejednokrotnie liczba osób, które mogą pojechać do innego domu pomocy, np. na bal karnawałowy, jest uzależniona od liczby miejsc $\mathrm{w}$ busie, którym dysponuje dom pomocy społecznej. Stąd wśród wypowiedzi dotyczących planów na najbliższe dni pojawiały się i takie:

Ierna [opiekunka] zdecyduje, czy pojade teraz czy nie.

To Pani zależy, jak sie zmieszcze do busa, to pojadę.

Drugi rodzaj planów pojawiających się spontanicznie w narracjach dotyczył zakupów, najczęściej odzieży: 
Teraz zbieram, bo chcę sobie garnitur na święta kupić.

Pojedziemy z opiekunka, to sobie nakupie bluzków i spodnie jakieś.

Powiem opiekunce, to mi kupi, co tam potrzebuje, sweter jakiś.

Plany związane z zakupami, to te najbliższe, najsamodzielniejsze i najbardziej realne do spełnienia, można zatem pokusić się o stwierdzenie, że mieszkańcy domów pomocy społecznej, nie musząc martwić się o potrzeby dnia codziennego, żyją trochę jak nastolatki, których plany, zwłaszcza te finansowe, dotyczą przede wszystkim zaspakajania własnych potrzeb - gromadzenie pieniędzy, aby kupić sobie potrzebną rzecz. Jednocześnie można zauważyć, że plany mieszkańców instytucji są $\mathrm{w}$ dużej mierze zredukowane do podstawowych potrzeb, tych, które mogą być realnie urzeczywistnione, a tym jest np. zakup odzieży, słodyczy czy innych drobiazgów. Przy czym w wypowiedziach niektórych osób pojawiły się zdania, które świadczą o tym, że nawet ta potrzeba została zredukowana u nich do minimum:

Powiem opiekunce to coś mi kupi....., mnie tam wszystko jedno, mnie się wszystko podoba.

Ta redukcja potrzeb wydaje się być charakterystyczna dla mieszkańców instytucji, o czym można przeczytać m.in. w książce Jakuba Niedbalskiego ${ }^{11}$.

W jednym wywiadzie pojawił się plan dotyczący samodzielnego mieszkania, plan realny, połączony z działaniem. Dodać należy, że wypowiedź ta pojawiła się spontanicznie $\mathrm{w}$ narracji badanego i związana była $z$ ogromnymi emocjami i koniecznością podjęcia bardzo ważnej, życiowej decyzji powiązanej z ryzykiem. Zarówno sama decyzja, jak i towarzyszące jej działania były bardzo ważne dla narratora:

To jest dla mnie ciężkie i trudne zdecydować się. Bo tu jestem 11 lat, tu mi pomagali, a tam dopiero wchodze. To jest ciężkie. To jest dla mnie

${ }^{11}$ J. Niedbalski, Żyć i pracować w domu pomocy społecznej, Wydawnictwo Naukowe UŁ, Łódź 2014. 
ciężkie, bardzo ciężkie, które wziąć. Bo mi tu dobrze jest. Bo też moge robić wszystko, co chcę. Jak będę sam mieszkat, to nie będzie na wyjazdy. W tym roku też jest plan jechać nad morze i ja mam problem, bo jak będzie mieszkanie, to nie będę mógł jechać nad morze. Muszę zdecydować, czy DPS, czy mieszkanie. To jest nasz dom.

Autor tej wypowiedzi jest osobą w szczególnej sytuacji życiowej, ma realną możliwość samodzielnego mieszkania poza instytucją. Wraz z opiekunami podjął działania zmierzające do realizacji planu, otrzymał propozycję mieszkania komunalnego, w którym mógłby zamieszkać. Jednakże, co wyraźnie podkreśla w wypowiedzi, boi się podjąć decyzję o rzeczywistej przeprowadzce do własnego mieszkania. Zdaje sobie sprawę, że życie w instytucji, choć niesie pewne ograniczenia, nie zmusza mieszkańców do zajmowania się codziennymi sprawami, jest życiem „na wiecznej kolonii”, na której co prawda trzeba czasem robić to, co nakazane, ale nie trzeba martwić się o opłaty, zakupy, pranie, posiłki i tym podobne. To zwolnienie od odpowiedzialności za własne życie jest wygodne, a zarazem wyuczone $\mathrm{w}$ praktyce dnia codziennego mieszkańca instytucji opieki.

W spontanicznych wypowiedziach pojawiały się także plany nierealne, choć cel został wyznaczony i pewne działania podjęte, dla przykładu:

Ożenię się, mam dziewuchę, już od 20 lat - przyjdzie czas to się zobaczy, jak będzie, jakoś to będzie, coś się wykombinuje, gdzieś się będzie mieszkać, do pracy się pójdzie. Ona to też w domu pomocy mieszka, ale mieszkanie po matce ma, to może i mieszkać by było gdzie, a pracować to ja moge, ale to, pani, kiedyś - mężczyzna, lat 74.

Słuchając mojego rozmówcy, miałam jednak wrażenie, że w gruncie rzeczy zdaje on sobie sprawę, że do realizacji tego planu nigdy nie dojdzie, jednak pojawia się on spontanicznie w wypowiedzi badanego i można się zastanowić, czy ten plan nie jest bardziej marzeniem czy nawet pewną nostalgią za "normalnym życiem” - takim, jakie mają inni. Od ponad 20 lat ten mieszkaniec domu pomo- 
cy społecznej ma „dziewczynę” mieszkającą w innym domu pomocy. Spotykają się ze się od czasu do czasu, wymieniają esemesy, częściej do siebie telefonują. Ponieważ miałam okazję rozmawiać z obojgiem, mogłam przekonać się, z jak wielkim uczuciem o sobie mówią. Czują się parą, chociaż dzieli ich odległość. Obydwoje z dumą opowiadali o partnerze, o tym, co od siebie dostali. W wypowiedzi mężczyzny pojawiał się zachwyt nad urodą i troskliwością kobiety:

Pani, ona to ładna jest, taka ma buźkę ładna, pamiętam, jak my się poznali, na takim konkursie teatrów, to ona przebrana była za góralke i takie korale miała i spódnice, ładnie wyglądała [...], a ile ona mi naprzywozi, kawy, herbaty, ciastka, cukier..., te Pani, ile tego mi nazwozi, a ja jej taka, no szta..., sztaku..., szkatułkę kupitem, taka, co to jak się otwiera, to gra, ale trzeba baterie.

W wypowiedzi kobiety także pojawia się temat „narzeczonego” jak mówi o swoim partnerze:

To my się już dtugo spotykamy, ja się tam martwię o niego, mówię, co ma zrobić $i$ już szykuje sobie, co mu zawioze [...], jak co dostane, to zawsze jedno dla niego i tak się uzbiera, to mu tam zawsze ciastków, herbaty czy cukru nawioze [...], ale on też o mnie dba, też częstuje i takie zdjęcie mam wspólne w pokoju.

Jednak, co należy podkreślić, w wypowiedzi kobiety nie pojawiły się plany wspólnej przyszłości, nawet zapytana o to, czy chciałaby zamieszkać razem z narzeczonym, kobieta stwierdziła:

Mowy nie ma, bo bym się bała, bo by mnie musiał krok w krok pilnować. Ja wole już tu mieszkać do śmierci.

Z wypowiedzi tych dwojga wywnioskować można, że mimo tego, że czują się parą, ich plany nie są wspólne - mężczyzna, choć nierealnie, myśli o ewentualnej wspólnej przyszłości, snuje plany, kobieta zdecydowanie nie. Z pewnością plany pozostaną na zawsze w sferze marzeń. 
Ponieważ, jak już wspomniałam, plany życiowe bardzo rzadko pojawiały się spontanicznie $\mathrm{w}$ narracjach badanych, często dopytywałam o nie i tu najczęściej pojawiały się odpowiedzi świadczące o braku planów:

Na razie nie mam planów.

Nie myślałem, nie wiem czy tu będę mieszkat, to jest niewiadoma

oraz wypowiedzi dotyczące zachowania status quo:

Mówiłem pani, że ja już nic nie zmienię, zostanie tak jak jest, a co tam będę zmieniać.

Jak bym zmienit, to tylko mogłoby być gorzej.

Pani jak ja już zacznę, to już w grobie będę mieszkat, ja mam 63, Pani, ani sie nie obejrzysz, a już będzie setka, patrz pani, niedawno była wiosna, a już zima, koniec roku, za pięć miesięcy będzie 64 lata, takie jest życie krótkie teraz, na tym świecie jest coraz gorzej. Stale się wala, kłóca, biją.

Zapytani o plany rozmówcy często mówili o przyszłości, jednocześnie ukazując ją jako niewiadomą, niesprecyzowaną, a właściwie niezaplanowaną:

Właśnie tego nie wiem, czy chciatbym sam mieszkać czy z rodzina. Może z rodzina, sam może kiedyś, ale w najbliższej przyszłości chciatbym cioci pomóc, bo się o ciocię martwię i o wujka, bo oni chorują i takie leki biora, że głowa boli. Chciałbym im pomóc.

Pytani o plany badani nawiązywali także do pracy, która w wielu wypowiedziach jawiła się jako zagrożenie:

Boje się takie coś, $i$ to jest to. Bo wypadki różne po ludziach chodza, jak to się mówi i to różnie bywa i jest ciężko. Pracować bym nie chciat.

Co do pracy, to nie, chora jestem. 
Teraz jak chce, to pomoge, a tak to bym musiała - wypowiedź kobiety, która od kilkunastu lat codziennie wstaje wcześnie rano i pomaga opiekunom w toalecie mniej sprawnych koleżanek.

Pracować to nie planuje, bo by mi rentę zabrali.

Praca zarobkowa uznana jest za zagrożenie niosące ze sobą utratę zdrowia lub finansów (renty), a także wolności: jak chcę, to pomogę. Osoby, które pytane o plany wspominały o pracy, były przeważnie tymi, które wykonywały określone zadania $\mathrm{w}$ domu pomocy społecznej z własnej woli. Były to prace porządkowe, pomoc przy opiece nad mniej sprawnymi mieszkańcami czy w przypadku mężczyzn - nawet drobne naprawy. Żaden z rozmówców nie planował podjęcia stałej pracy nawet na terenie domu pomocy społecznej (jeśli istniałaby taka możliwość). Wiąże się to prawdopodobnie $\mathrm{z}$ wieloma aspektami, ale także z brakiem konieczności podjęcia pracy zarobkowej.

Plany życiowe dorosłych mieszkańców domów pomocy społecznej dla osób z niepełnosprawnością intelektualną rozpatrywać należy, uwzględniając przede wszystkim wiek, stopień niepełnosprawności intelektualnej i środowisko, w którym przebywają badani. Moimi rozmówcami były osoby dorosłe w wieku od 24 do 74 lat. Duża rozpiętość wiekowa nie była czynnikiem różnicującym plany, jedynym wyjątkiem był opisany już wyżej plan trzydziestoparoletniego mężczyzny z lekkim stopniem niepełnosprawności intelektualnej, dotyczący samodzielnego zamieszkania w mieszkaniu komunalnym. W rozważaniu o planach należy brać także pod uwagę stopień niepełnosprawności intelektualnej (lekki lub umiarkowany) i związane z nim realne możliwości przewidywania przyszłości, stąd u niektórych rozmówców pojawiające się plany nierealne. Następnym czynnikiem, którego nie można pominąć w przypadku planowania, to środowisko, w jakim żyją badani. W tym przypadku są to domy pomocy społecznej, a więc instytucje, które ze swej natury są środowiskiem dyrektywnym, nastawionym wprawdzie na pomoc i opiekę, ale posiadającym reguły, regulaminy, rozkłady dnia, a także narzucającym wybrane aktywności mieszkańcom. Jest 
to więc środowisko, które najprawdopodobniej nie sprzyja tworzeniu planów.

Plany życiowe dorosłych mieszkańców domów pomocy społecznej dla osób z niepełnosprawnością intelektualną można scharakteryzować następująco ${ }^{12}$ :

- zakres - najczęściej jeden plan składowy i to przeważnie dotyczący zachowania dotychczasowego stanu rzeczy lub związany z zakupami, które będą dokonane najbliższej przyszłości, rzadziej kilka planów - przykładem złożonego, wielowątkowego planu może być ten dotyczący mieszkania poza DPS-em - związany z większym trudem jego realizacji i dłuższym czasem, jednak, na co wskazywał rozmówca, wysiłek jego skupiony jest przede wszystkim na podjęciu decyzji, czy realizować ów plan, mniej - w jaki sposób ma być zrealizowany;

- treść - najczęściej prosta, nierozbudowana, jak już wcześniej wspomniałam, często związana z podstawowymi potrzebami;

- różnorodność - najczęściej jedna dziedzina życia, np. zakupy;

- liczba - jeśli w ogóle się pojawia, to jest to jeden plan, nawet badany, który brał pod uwagę realizację planu związanego z mieszkaniem poza instytucją, pomimo tego, że plan ten powinien wiązać się z planem poszukiwania i podjęcia pracy zawodowej, był w gruncie rzeczy pojedynczym planem; mój rozmówca $\mathrm{w}$ swojej opowieści nie snuł planów związanych z ewentualnym zatrudnieniem;

- stopniem trudności - niskie aspiracje, niska samoocena w związku z tym plany także dotyczą przede wszystkim przyziemnych spraw, tych najłatwiejszych do realizacji;

- stopnień ważności - trudny do ocenienia, najczęściej plany nie były ważne dla badanego - nie podejmowali oni działań zmierzających do ich realizacji, być może czekali, aż ktoś z zewnątrz pomoże w ich realizacji lub zrealizuje je za jednostkę, można także sądzić, że badani nie wierzą, aby plan mógł być rzeczywiście zrealizowany; w przypadku mężczyzny, który

12 T. Mądrzycki, op. cit., s. 116. 
miał możliwość samodzielnego mieszkania poza instytucją, można mówić o ważności planu - przy czym ważna i trudna była sama decyzja, czy realizować plan, czy nie, ważność samego planu trudna jest do jednoznacznego ocenienia. Można zaryzykować stwierdzenie, że gdyby plan związany z samodzielnym mieszkaniem był ważny sam w sobie, mężczyzna podjąłby konkretne działania i zrealizował go. Jednak obawy, wahania, nie tylko dotyczące kwestii „czy sobie poradzę”, ale także tego, że owszem, coś zyskam, ale z pewnych rzeczy będę musiał zrezygnować, świadczą, że plan nie jest zinterioryzowany przez mężczyznę. Z jego narracji wywnioskować można, że czuje się on wyróżniony tym, że zarówno koledzy, jak i personel domu pomocy społecznej wierzą, że dałby radę samodzielnie mieszkać, o czym świadczą wypowiedzi:

Tu mi wszyscy mówia, że dam radę $i$ pan dyrektor, $i$ wszyscy, $i$ ja wiem, że porzadek to ja bym miat i gotować umiem, i prać, i pracować też potrafie.

O braku uwewnętrznienia planu świadczy także fakt, że mężczyzna miał już rok wcześniej przyznane mieszkanie komunalne, ale $\mathrm{w}$ ostatniej chwili $\mathrm{z}$ niego zrezygnował, a obecnie jest znowu jednym z pierwszych na liście oczekujących na przydział lokalu. Teoretycznie ma on przygotowaną mapę realizacji planu, wie, jakie czynności musi podjać, ma nawet zebraną część wyposażenia mieszkania, jednak w praktyce plan ten wydaje się bardziej zewnętrznym planem opiekunów, którzy znając mieszkańca, mają świadomość, że mógłby być samodzielnym człowiekiem, który zarabia na siebie, ma mieszanie, jest samodzielny, niż planem samego podopiecznego;

- realność - plany mieszkańców domów pomocy społecznej dla osób z niepełnosprawnością intelektualną były albo bardzo realne i przyziemne, głównie związane z zakupami, jednocześnie dość często pojawiały się plany nierealne, jak choćby opisany wyżej plan ożenku snuty przez 74-letniego mężczyznę; 
- szczegółowość - mało sprecyzowane, brak opracowanych map realizacji planów; przyznać należy, że opisywane plany w większości były nierozwinięte, stąd brak mapy planów, te dotyczące zakupów opierały się raczej na przekonaniu, że w odpowiednim czasie opiekun poinformuje mieszkańca o dostatecznej ilości pieniędzy na dokonanie zakupu;

- elastyczność - nieelastyczne, sztywne plany, co wynika najprawdopodobniej $\mathrm{z}$ jednej strony $\mathrm{z}$ samej istoty niepełnosprawności intelektualnej i związanymi z nią zaburzeniami poznawczymi, $z$ drugiej $z$ przyczyn środowiskowych min wyuczonej bezradności i bierności;

- poziom integracji - hierarchia - bywają skrajne albo najważniejsze choć czasem nierealne (rzadko występują w wypowiedziach) albo mało ważne - jednostka nie utożsamia się z planem (te częściej ukazują się w wypowiadanych treściach);

- zgodne z normami moralnymi - wszystkie omawiane plany były zgodne z obowiązującymi normami moralnymi i społecznymi.

\section{Marzenia mieszkańców domów pomocy społecznej}

W narracjach badanych temat marzeń nie pojawiał się spontanicznie. Odpowiedzi dotyczące marzeń zawsze były odpowiedzią na postawione przeze mnie pytanie: „O czym Pan/Pani marzy?”. I tu z reguły następowała dłuższa chwila ciszy, po której pojawiły się nieliczne odpowiedzi. Dokonałam próby ich kategoryzacji w następujące grupy: marzenia o "rzeczach wielkich”, marzenia dotyczące bliskich, „sny o potędze”, brak marzeń.

Marzenia o „rzeczach wielkich”: w wypowiedziach kilku rozmówców pojawiły się marzenia, które moglibyśmy sklasyfikować jako marzenia idealistyczne, dotyczące bezpieczeństwa, pokoju na świecie, szczęścia:

Żeby na świecie dobrze było, bo teraz to strach, jak w tej telewizji mówia, co to się dzieje. 
Marzę o takich dużych rzeczach. Żeby mojej rodzinie się takie rzeczy nie zdarzały, niedawno moja mama zmarta i kuzynka teraz, żeby się takie rzeczy nie przydarzaty,

Żeby się ludzie nie bili, bo tu niekiedy się bija, żeby spokój byt.

Drugą grupę marzeń stanowiły te dotyczące posiadania kogoś bliskiego, kontaktów z bliskimi. W wypowiedziach pojawiają się potrzeby kontaktu mieszkańców domu pomocy społecznej z bliskimi lub znalezienia kogoś, kto byłby "tylko dla mnie":

Żeby mieć kogoś blisko siebie, żeby się dogadać. Tylko to mam życzenie, a resztę się ułoży...

O swojej rodzinie na przykład. Chciałabym, żeby mój brat mnie odwiedzit. No wiele razy obiecat, że przyjedzie.

Marze $i$ sie ciesze, że na imieniny w marcu przyjada, na Krystyny 13 marca.

Gdzieś do rodziny, choć na trochę pojechać.

Mieszkanie wśród wielu osób, posiadanie koleżanek czy kolegów, kontakt z opiekunami czy osobą pierwszego kontaktu, choć ważny, nie zaspakaja potrzeby posiadania kogoś „na zewnątrz”, co szczególnie słychać w wypowiedzi jednego z mieszkańców domu pomocy:

Byle, żeby mnie ktoś wziąt na święta albo na urlop jakiś wypoczynkowy. Nawet te pięć dni, nawet te cztery dni.

Autor ostatniej wypowiedzi był ogromnie zdeterminowany na znalezienie bądź odnowienie kontaktu z kimś, kogo znał w przeszłości, a z kim nie miał kontaktu od 40 lat (odkąd mieszka w domu pomocy). Potrzebę wyjechania z domu choć na kilka dni, nazwaną urlopem, można być może zinterpretować jako chęć odpoczynku od rutyny, codzienności, przeżycia czegoś, co byłoby wreszcie indywidualne. 
Inną grupę marzeń stanowią te, które nazwałabym „sny o potędze", marzenia te są charakterystyczne dla nas wszystkich i należą do kategorii tych, które najprawdopodobniej nie spełnią się:

To nie wiem. Chciałabym wygrać w totolotka. To bym sobie kupiła mieszkanie w Zakopanem [śmiech].

Ta kategoria marzeń pojawiła się tylko w jednej wypowiedzi.

Najczęściej jednak moi rozmówcy na pytanie o marzenia odpowiadali:

No nie wiem. Co by tu powiedzieć. O niczym.

Nie ma kasy, nie ma marzeń.

Pani przestań, ja nie mam marzeń.

Nie rozumiem... O czym marze?...No nie wiem, o niczym.

Nie rozumiem, marzenia, nie wiem o co chodzi.

Brak marzeń lub przekonanie, że są one do niczego niepotrzebne, były najczęstszą reakcją na pytanie o marzenia. Sądzić można, że instytucja pomocowa jest niestety miejscem, gdzie marzenia być może są niepotrzebne, a część z nich można odebrać jako marzenia przynoszące gorycz (np. w wypowiedzi pana marzącego o wyjechaniu z DPS-u choć na kilka dni).

\section{Podsumowanie}

Plany i marzenia rzadko pojawiają się w spontanicznych narracjach badanych, jeśli już są, bardzo często są zredukowane, sądzić można, że na taki stan rzeczy ma wpływ wiele czynników wynikających z całożyciowych doświadczeń badanych. Zarówno, jak można sądzić, wychowanie osób z niepełnosprawnością intelektualną, jak i życie $w$ instytucji nie sprzyja snuciu planów i marzeń. $Z$ analizy materiału wywnioskować można, że mieszkańcy domów pomo- 
cy społecznej żyją z dnia na dzień, bez konieczności tworzenie planów na przyszłość, a być może nawet słuszne byłoby stwierdzenie, że instytucja opieki jest czynnikiem nie tylko redukującym, ale wręcz uniemożliwia snucie planów życiowych. Należy także pamiętać, że większość mieszkańców, choć deklarująca zadowolenie z pobytu w domu pomocy społecznej, nie znalazła się tam z własnej woli czy inicjatywy. To najczęściej inne osoby zdecydowały za nie o umieszczeniu w instytucji opieki. Być może także ten fakt spowodował, że mieszkańcy nie snują planów, ponieważ doświadczyli już wcześniej, że to nie oni decydują o swoim życiu, kontrolę nad ich losami przejęły osoby trzecie: opiekunowie, dyrekcja, personel instytucji, rodzina... Plany zdają się nie mieć większego znaczenia w ich życiu, a marzenia być może są nawet zbędnym luksusem. Stwierdzić więc można, że zarówno plany życiowe, jak i marzenia nie pełnią funkcji regulującej życie omawianej grupy osób.

\section{Bibliografia}

Cantor N., Kihlstrom J.F., Personality and social intelligence, Englewood Cliffs, New Jersey, Prentice-Hall 1987.

Dymara B., Droga do marzeń, czyli o potrzebie rozwijania wyobraźni, [w:] Dziecko w świecie marzeń, red. B. Dymara, Oficyna Wydawnicza „Impuls”, Kraków 1999.

Maruszewski T., Psychologia poznania, Gdańskie Wydawnictwo Psychologiczne, Gdańsk 2002.

Mądrzycki T., Osobowość jako system tworzący i realizujący plany. Nowe podejście, Wydawnictwo Uniwersytetu Gdańskiego, Gdańsk 2002.

Niedbalski J., Żyć i pracować w domu pomocy społecznej, Wydawnictwo Naukowe UŁ, Łódź 2014.

Szewczuk W., Psychologia. Zarys podręcznikowy T.2, Wydawnictwo Naukowe PWN, Warszawa 1966.

Zimbardo P., Psychologia i życie, PWN, Warszawa 1999. 